\title{
THE USE OF GAME THEORY IN URBAN TRANSPORT PLANNING
}

\author{
Jasmina Pašagić Škrinjar, Borna Abramović, Nikolina Brnjac
}

Preliminary notes

Every day the traffic is becoming more complex, especially traffic in big cities. In order to make efficient decisions on the traffic organization in cities various activities are necessary: gathering, grouping, selection, and data analysis, then usage of quantitative and simulation methods as base for decisionmaking, regardless of the decision-making level: strategic, tactical or operative decisions. Within quantitative decision-making methods special place belongs to the game theory. The paper presents how additional information is included in the mathematical model in order to make the optimal decision. In general, the mathematical model of selecting the destination terminal has been processed and the numerical example has been presented for better explanation of the selection procedure.

Keywords: decision-making; game theory; organization of urban transport; transport planning

Uloga teorije igara u planiranju gradskog prijevoza

Prethodno priopćenje

Svakim danom promet postaje sve kompleksniji, pogotovu promet u velikim gradovima. Kako bi se donijele dobre odluke o organizaciji prometa u gradovima potrebne su različite aktivnosti: prikupljanje i obrada podataka, analiza podataka, uporaba kvantitativnih i simulacijskih metoda kao podloge za odlučivanja, bilo da se radi o strateškim, taktičkim ili operativnim odlukama. Među kvantitativnim metodama odlučivanja posebno mjesto zauzima teorija igara. U radu je pokazano kako se dodatne informacije uključuju u matematički model da bi se donijela optimalna odluka. Obrađen je općenito matematički model izbora odredišnog terminala te je dan numerički primjer radi boljeg objašnjenja procedure izbora.

Ključne riječi: odlučivanje; organizacija prometa u gradovima; prometno planiranje; teorija igara

\section{Introduction}

Since traffic, especially in big cities, has become more and more complex and complicated, it is necessary to use various quantitative methods and simulation methods for making correct decisions in the organization and management of urban transport. Special role belongs to scientific disciplines: the decision-making theory and the game theory [5].

Decision-making, decision-making theory, decisionmaking process, business, managerial, organizational decision-making, decision, all these are words and terms which are used extremely frequently. This is done both in scientific and professional approaches and in everyday life. The urban transport is continuously increasing and has become a complex process, so that also the activity of "decision-making" has become more difficult and accountable. Different consequences can be expected for single decisions.

The decision-making is an extremely interdisciplinary process, and it is therefore difficult both to be studied and successfully implemented. The decision-making theory relies on many scientific disciplines: philosophy, economics, statistics, sociology, psychology, law, political science, mathematics, operational research, game theory, etc. [1].

Mathematics, as scientific discipline occurs in the processes of traffic decision-making, primarily through the development of mathematical models and their usage in order to analyze the situations from the real life and for the optimisation of the set goals. Not only are the socalled routing problems in urban logistics researched today, but they are also implemented.

The theory of matrix games has special significance in the decision-making process. The theory of matrix games is one of the mathematical disciplines, i.e. it is a special area of operational studies [7]. Decision-making is an important part of the job of the traffic professionals related to planning, monitoring, and selection of optimal solutions from the set of the possible ones. The traffic professionals make daily decisions and they can use as one universal method for decision-making the quantitative decision-making methods, primarily the matrix games. The traffic professionals apply in fact the developed methods of matrix games to their problems using various software tools. The main activity of traffic professionals is to estimate the value of payment matrix. If the payment matrix elements are not well estimated, if they do not describe the real situation, the usage of even the best methods as well as the well developed software tools will fail to yield real results [9]. The quantitative decisionmaking methods are as good as the data which are the base for decision-making. Combining of databases and method bases, controlled by the users, is the basic characteristic of decision-making.

And finally, what needs to be emphasised is the latest trend in the decision-making area which represents an attempt at integration of expert systems and the systems for decision-making support into a new category, the socalled intelligent decision-making support systems [4].

Decision usually understands "intellectual result" in a current process of evaluating alternatives which is performed in order to reach a certain goal in which the expectations of specific action force the decision-maker to select an action which most likely results in achieving the already set goal.

In this way the science on decision-making (decisionmaking theory) has developed as a process which, using scientific methods and systemic research, helps the decision-maker in determining the optimal action. What should be considered here is that the decision-making theory cannot completely replace the approach of the socalled intuitive decision-making. Every decision-maker, whether familiar with the decision-making theory or not, 
usually keeps the right to a certain level of personal judgement: the decision-making theory should help their judgement to be maximally successful.

When mathematical models are used to make decisions certain preliminary activities need to be done [2]. First, one should determine the parameters (only the measurable ones for mathematical modelling) which affect the final result. For every parameter one needs to define the value intervals which are of significance for the studied problem. The researcher defines the mathematical model for the events they want to study.

The game theory is the behaviour in conflict situations. The game theory includes also the conflict situations that have almost no relation to games. Let us take the example of determining the destination stations of the new urban transport line. The behaviour of potential passengers and urban transport company managers have the role of players in thus understood conflict situation.

In solving the control actions in traffic, in the conditions of absence of the necessary information, it should be kept in mind that there will always be present an element of uncertainty regarding the outcome of the control action. In other words, a certain risk will be present that can be expressed quantitatively as a certain loss [8].

Mathematical methods which are used to solve such management tasks are known as special disciplines: game theory and statistical decision-making methods.

\section{Decision-making with incomplete information}

It is often necessary in cities to make a decision on the location for instance of a bus stop, warehouse, distribution centre, customer service, airport, ambulance, entries and exits from highways, etc. Many quantitative methods for solving location problems have been developed. For planning with incomplete data most often the quantitative methods are used: decision-making analysis, simulations, game theory, Markov analysis, linear and non-linear programming [11]. This paper analyzes the procedure for solving of transport location problems using matrix games. Often the urban transport solutions include conflicts of interests of one group of citizens with those of another group of citizens or a business subject. The traffic decisions most often yield some benefit or advantage to one group of citizens or a business subject at the expense of another group or a business subject, creating conflict situations. To make optimal decisions using quantitative methods with conflict situations it is necessary to know certain measurable parameters or know their statistics. The researcher defines most often a statistical model for the process they want to study in order to make optimal decisions.

In solving the management actions in traffic by means of game theory, under conditions of incomplete information, as stated earlier, it is necessary to have in mind that there will always be an element of uncertainty regarding the outcome of the management action. In other words, there will be a certain risk, which can be expressed quantitatively as a loss e.g. the number of unoccupied places on the bus.
Measuring of traffic parameters and surveying are usually used in order to make traffic decisions especially in urban transport with high level of complexity. In order to use the data in game models they have to be properly processed [10].

The location of fixed destinations, e.g.: warehouses, production plants, bus stops, servicing centres, etc. forms the entire logistic system including traffic as the subsystem of the logistic system. Such problems are called problems of determining the optimal location, and they are solved by quantitative methods if the problem has the property of a conflict situation, the game theory can be used [9].

\section{Implementation of matrix games for the selection of bus destination in the city}

Let us assume that a new settlement has been created in a city, and it needs to be connected with other parts of the city by means of a new urban transport line. Urban transport company wants to open a new transport line. It is necessary to make a decision on the selection of a new line on the existing urban transport network in order to ensure fast and efficient passenger transport from the new settlement to the location of employment /education/ other, in different parts of the city and thus enable integral passenger transport.

The question is how the game theory can be used, in order to determine the best line according to the set criteria from the set of possible potential lines. For the solution of the problem it is necessary to define the structure of the statistical game $(\Omega, A, L)$, set of potential users $\Omega$, set of strategies (decisions) $A$, and the game value $L$. The set of potential users $\Omega=\left\{\omega_{1}, \omega_{2}, \ldots, \omega_{\mathrm{i}}\right\}$ where $\omega_{1}$ are residents of the new settlement connected to destination $A_{1}$ in the city, it is e.g. their place of work, $\omega_{2}$ are residents of the new settlement connected to destination $\mathrm{A}_{2}$, and so on [6]. Set of decisions $A=\left\{a_{1}, a_{2}\right.$, $\left.\ldots, a_{\mathrm{i}}\right\}$, where $\mathrm{a}_{1}$ matches the line from the new settlement to destination $A_{1}$ in the city, $a_{2}$ is the decision for the second line from the new settlement to destination $A_{2}$, and so on (Fig. 1):

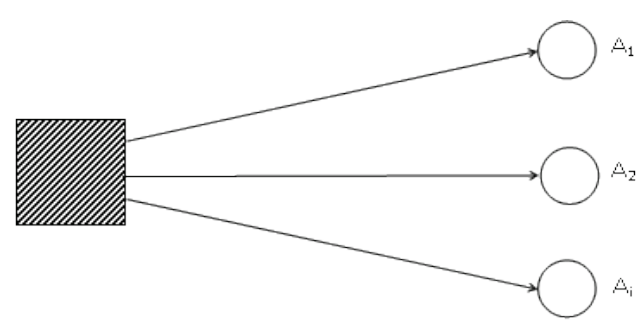

Figure 1 Potential lines Source: developed by the author

The optimality of the solution depends on the quality of the estimate of the connection of the new settlement residents with certain points in the city.

If a new line is opened on which the expected transport demand is not realized, this line will not be sufficiently used i.e. eventually it will fail to have the economic justification [8]. This will cause loss proportional to the number of unoccupied seats on the bus. The marketing service of the urban transport company can assess for a set of potential users $\Omega=\left\{\omega_{1}, \omega\right.$ 
$\left.2, \ldots, \omega_{i}\right\}$ how many free seats will remain on the bus; let

Tab. 1 be the matrix of losses or the matrix of payments $L(\Omega, A)$.

The initial statistical game is transformed into statistical game $(\Omega, D, R)$, recognizing additional statistical information [6]. For instance, data can be gathered by surveying the residents of the new settlement [3]. One of the questions in the survey is whether they prefer a line to destination $A_{1}$ in the city, or $A_{2}$ or $A_{i}$. Another question is whether they will use this line on departure and arrival if on arrival there are several alternative lines. The questions need to be YES or NO questions.

Table 1 Matrix of losses

\begin{tabular}{|c|c|c|c|}
\hline$A$ & $a_{1}$ & $\ldots$ & $a_{j}$ \\
\hline$\Omega$ & $L\left(\omega_{1}, \mathrm{a}_{1}\right)$ & $\ldots$ & $\ldots$ \\
$\ldots$ & $\ldots$ & $\ldots$ & $\ldots$ \\
$\omega_{1}$ & $\ldots$ & $\ldots$ & $L\left(\omega_{i}, a_{j}\right)$ \\
\hline
\end{tabular}

A set of answers of this experiment (survey) is vector $X=\left\{x_{1}, x_{2}, \ldots, x_{k}\right\}$, where $x_{1}$ designates that a part of surveyed potential users prefers the line to destination $A_{1}$, $x_{2}$ prefer the line to $A_{2}$, etc. e.g. $x_{\text {i }}$ prefers the line to $A_{i}$ and finally, $x_{k}(k=i+1)$ is a part of respondents who do not prefer either of the two offered lines, that all the lines are equally interesting to them.

The distribution of probabilities of the results $x_{1}, x_{2}, \ldots$, $x_{k}$ depending on data $\omega_{1}, \omega_{2}, \ldots, \omega_{\mathrm{i}}$, that were indicated in the survey as the place of work, are:

$P\left\{x_{i} \mid \omega_{j}\right\}, i=1,2, \ldots, k j=1,2, \ldots, n$

Function $\mathrm{d}\left(x_{i}\right)=a_{j}$ is introduced, which maps set $X$ into set $A$. All the possible variations with iteration are studied i.e. the selection of $k$ elements $\left\{x_{1}, x_{2}, \ldots, x_{k}\right\}$ from $i$ element $\left\{a_{1}, a_{2}, \ldots, a_{i}\right\}$, of which there are $i^{k}$, these are elements of set $D=\left\{d_{1}, d_{2}, \ldots, d_{n} \mid n=i^{k}\right\}$ [7]. Tab. 2 shows some elements from set $D$ for set $X=\left\{x_{1}, x_{2}, x_{3}\right.$, $\left.x_{4}\right\}$ and set $A=\left\{a_{1}, a_{2}, a_{3}\right\}$

Table 2 Elements of set $X$ and set $A$

\begin{tabular}{|c|c|c|c|c|c|c|}
\hline$x^{d}$ & $d_{1}$ & $d_{2}$ & $d_{3}$ & $d_{4}$ & $d_{5}$ & $\ldots$ \\
\hline$x_{1}$ & $a_{1}$ & $a_{1}$ & $a_{1}$ & $a_{1}$ & $a_{2}$ & $\cdots$ \\
\hline$x_{2}$ & $a_{2}$ & $a_{2}$ & $a_{2}$ & $a_{1}$ & $a_{2}$ & $\ldots$ \\
\hline$\cdots$ & $\cdots$ & $\cdots$ & $\ldots$ & $\cdots$ & $\ldots$ & $\cdots$ \\
\hline$x_{k}$ & $a_{1}$ & $a_{2}$ & $a_{3}$ & $a_{1}$ & $a_{2}$ & $\ldots$ \\
\hline
\end{tabular}

Based on the function of expected losses $L(\Omega, A)$ presented in Tab. 1 and the probability $P\left\{x_{i} \mid \omega_{j}\right\}$ the matrix of risk:

$R\left(\omega_{i}, d_{j}\right)=P\left(x_{i} \mid \omega_{j}\right) L\left(\omega_{i}, d_{j}(X)\right)$

Thus the table of risk is obtained. If there is no saddle point in the table of risk the problem is reduced to linear programming [9]. The selection of the optimal line will be shown on a numerical example.

\section{$4 \quad$ Numerical example}

Let the set of decisions be $A=\left\{a_{1}, a_{2}, a_{3}\right\}$, where $a_{1}$ corresponds to the route from the new settlement to destination $A_{1}$ in the city, $a_{2}$ is the decision for the second route from the new settlement to destination $A_{2}, a_{3}$ is the third route from the new settlement to destination $A_{3}$ in the city. Destination $A_{2}$ is in the very centre of the city, and terminals $A_{1}$ and $A_{3}$ are away from the very centre of the city.

The optimality of solutions $a_{1}, a_{2}, a_{3}$ depends on the unknown structure of the residents of the new settlement and their connection to certain locations in the city [6].

Let the set of conditions of connection to certain locations in the city be $\Omega=\left\{\omega_{1}, \omega_{2}, \omega_{3}\right\}$, where $\omega_{1}$ means that the majority of residents of the new settlement work near destination $A_{1}$ in the city, $\omega_{2}$ near destination $A_{2}$ and $\omega_{3}$ near destination $A_{3}$ in the city.

As mentioned previously, if the urban transport company sets a new route that does not suit the residents of the new settlement, this line will fail to be fully used i.e. it will not be economically justified. This will cause losses to the urban transport company proportional to the number of unoccupied seats on the bus. The matrix of losses $L(\Omega, A)$ is presented in Tab. 3 .

Table 3 Matrix of losses
\begin{tabular}{|c|c|c|c|}
\hline$\omega$ & $a_{1}$ & $a_{2}$ & $a_{3}$ \\
\hline$\omega_{1}$ & 0 & 5 & 10 \\
$\omega_{2}$ & 5 & 0 & 5 \\
$\omega_{3}$ & 10 & 5 & 0 \\
\hline
\end{tabular}

In order to make the final decision about the new line the marketing service of the urban transport company organizes gathering of data by a survey questioning the residents of the new settlement which destinations in the city they prefer [6].

The set of answers of this experiment (survey) is vector $X=\left\{x_{1}, x_{2}, x_{3}, x_{4}\right\}$, where $x_{1}$ denotes that the interviewed residents of the new settlement prefer destination $A_{1}, x_{2}$ destination $A_{2}, x_{3}$ destination $A_{3}$, and finally, $x_{4}$ denotes the residents who have no special preference of any of the destinations.

Let the distribution of the probabilities of the results $x_{1}$, $x_{2}, x_{3}, x_{4}$ depending on the initial data $\omega_{1}, \omega_{2}, \omega_{3}$, that were indicated in the survey as the place of work, be:

$P\left\{x_{1} \mid \omega_{1}\right\}=0,7$
$P\left\{x_{1} \mid \omega_{2}\right\}=0,1$
$P\left\{x_{2} \mid \omega_{1}\right\}=0,2$
$P\left\{x_{2} \mid \omega_{2}\right\}=0,7$
$P\left\{x_{3} \mid \omega_{1}\right\}=0,05$
$P\left\{x_{3} \mid \omega_{2}\right\}=0,1$
$P\left\{x_{4} \mid \omega_{1}\right\}=0,05$
$P\left\{x_{4} \mid \omega_{2}\right\}=0,1$
$P\left\{x_{1} \mid \omega_{3}\right\}=0,05$
$P\left\{x_{2} \mid \omega_{3}\right\}=0,2$
$P\left\{x_{3} \mid \omega_{3}\right\}=0,7$
$P\left\{x_{4} \mid \omega_{3}\right\}=0,05$

Function $\mathrm{d}(x)=a$ is introduced, which maps set $X$ into set $A$. All the possible variations are studied, i.e. the selection of four elements $\left\{x_{1}, x_{2}, x_{3}, x_{4}\right\}$ of three elements 
$\left\{a_{1}, a_{2}, a_{3}\right\}$ out of which there are $3^{4}=81$, these are the elements of set $D=\left\{d_{1}, d_{2}, \ldots, d_{81}\right\}$. Not all 81 possible outcomes of the experiment need to be studied, for this case six elements can be taken, Tab. 4 . In the first three cases $x_{1}$ is correspondent to $a_{1}, x_{2}$ to $a_{2}$ and $x_{3}$ to $a_{3}$. The responses that were classified under $x_{4}$ will be taken once as $a_{1}$, the second time as $\mathrm{a}_{2}$ and the third time as $a_{3}$. Still cases are studied when all $x$-s are assigned $a_{1}$, then $a_{2}$ and finally $a_{3}$.

Table 4 Selected sample of correspondent links

\begin{tabular}{|c|c|c|c|c|c|c|}
\hline$d$ & $d_{1}$ & $d_{2}$ & $d_{3}$ & $d_{4}$ & $d_{5}$ & $d_{6}$ \\
\hline$x_{1}$ & $a_{1}$ & $a_{1}$ & $a_{1}$ & $a_{1}$ & $a_{2}$ & $a_{3}$ \\
\hline$x_{2}$ & $a_{2}$ & $a_{2}$ & $a_{2}$ & $a_{1}$ & $a_{2}$ & $a_{3}$ \\
\hline$x_{3}$ & $a_{3}$ & $a_{3}$ & $a_{3}$ & $a_{1}$ & $a_{2}$ & $a_{3}$ \\
\hline$x_{4}$ & $a_{1}$ & $a_{2}$ & $a_{3}$ & $a_{1}$ & $a_{2}$ & $a_{3}$ \\
\hline
\end{tabular}

Based on the function of the expected losses $L(\Omega, A)$ given in Tab. 3 and probabilities $P\left\{x_{i} \mid \omega_{j}\right\}$ the function of risk $R(\Omega, D)$ can be calculated for the selected $d_{i}$ which are presented in Tab. 5 .

The function of risk is calculated according to (2):

$$
\begin{aligned}
& R\left\{\omega_{1}, d_{1}\right\}=0 \cdot 0,7+5 \cdot 0,2+10 \cdot 0,05+0 \cdot 0,05=1,5 \\
& R\left\{\omega_{1}, d_{2}\right\}=0 \cdot 0,7+5 \cdot 0,2+10 \cdot 0,05+5 \cdot 0,05=1,75 \\
& R\left\{\omega_{2}, d_{1}\right\}=5 \cdot 0,1+0 \cdot 0,7+5 \cdot 0,1+5 \cdot 0,1=1,5 \\
& R\left\{\omega_{2}, d_{2}\right\}=5 \cdot 0,1+0 \cdot 0,7+5 \cdot 0,1+0 \cdot 0,1=1 \\
& R\left\{\omega_{3}, d_{1}\right\}=10 \cdot 0,05+5 \cdot 0,2+0 \cdot 0,7+10 \cdot 0,05=2 \\
& R\left\{\omega_{3}, d_{2}\right\}=10 \cdot 0,05+5 \cdot 0,2+0 \cdot 0,7+5 \cdot 0,05=1,75
\end{aligned}
$$

and so on can be calculated in order to obtain the function of risk in the form of a matrix

Table 5 Functions of risk

\begin{tabular}{|c|c|c|c|c|c|c|c|}
\hline$D$ & $d_{1}$ & $d_{2}$ & $d_{3}$ & $d_{4}$ & $d_{5}$ & $d_{6}$ & $\min$ \\
\hline$\omega_{1}$ & 1,5 & 1,75 & 2 & 0 & 5 & 10 & 0 \\
$\omega_{2}$ & 1,5 & 1 & 1,5 & 5 & 0 & 5 & 0 \\
$\omega_{3}$ & 2 & 1,75 & 1,5 & 10 & 5 & 0 & 0 \\
\hline $\max$ & 2 & 1,75 & 2 & 10 & 5 & 10 & \\
\hline
\end{tabular}

Tab. 5 shows that there is no saddle point. The game can be solved by linear programming i.e. a combined strategy is requested. The probabilities $p_{1}=P\left(d_{1}\right), p_{2}=$ $P\left(d_{2}\right), p_{3}=P\left(d_{3}\right), p_{4}=P\left(d_{4}\right), p_{5}=P\left(d_{5}\right), p_{6}=P\left(d_{6}\right)$ are introduced.

The adequate task of linear programming is [2]:

$\min v$

$1,5 p_{1}+1,75 p_{2}+2 p_{3}+5 p_{5}+10 p_{6} \leq v$

$1,5 p_{1}+p_{2}+1,5 p_{3}+5 p_{4}+5 p_{6} \leq v$

$2 p_{1}+1,75 p_{2}+1,5 p_{3}+10 p_{4}+5 p_{5} \leq v$

$p_{1}+p_{2}+p_{3}+p_{4}+p_{5}+p_{6}=1$

$p_{1} \geq 0, p_{2} \geq 0, p_{3} \geq 0, p_{4} \geq 0, p_{5} \geq 0, p_{6} \geq 0$

since $v>0$, the above three inequalities are divided by $v$ and a new variable $y_{i}=\frac{p_{i}}{v}$ is introduced.

The following task of linear programming is obtained:

$$
\begin{aligned}
& \max z=\frac{1}{v}=y_{1}+y_{2}+y_{3}+y_{4}+y_{5}+y_{6} \\
& 1,5 y_{1}+1,75 y_{2}+2 y_{3}+5 y_{5}+10 y_{6} \leq 1 \\
& 1,5 y_{1}+y_{2}+1,5 y_{3}+5 y_{4}+5 y_{6} \leq 1 \\
& 2 y_{1}+1,75 y_{2}+1,5 y_{3}+10 y_{4}+5 y_{5} \leq 1 \\
& y_{1} \geq 0, y_{2} \geq 0, y_{3} \geq 0, y_{4} \geq 0, y_{5} \geq 0, y_{6} \geq 0
\end{aligned}
$$

Using the simplex procedure or a software tool the basic optimal solution can be obtained. For this example the solution was obtained by means of the software tool WinQSB:

$y_{1}=\frac{2}{7}, \mathrm{y}_{2}=0, y_{3}=\frac{2}{7}, y_{4}=0, y_{5}=0, y_{6}=0$.

$z=\frac{4}{7}$, hence the value of the game $v=\frac{7}{4}$

Now the following can be calculated $y_{i}=\frac{p_{i}}{v}, p_{2}=0, p_{3}$ $=\frac{1}{2}, p_{4}=0, p_{5}=0, p_{6}=0$.

In this way, the minimax random function $\delta_{0}$ has the following distribution of probabilities:

$P\left\{d_{1}\right\}=\frac{1}{2}, P\left\{d_{3}\right\}=\frac{1}{2}$.

This means that $\delta_{0}$ has combined strategy with equal probability of pure strategies $d_{1}$ and $d_{3}$, which differ one from another only by the result $x_{4}$ of the statistical experiment.

According to data collected through the new settlement residents equally favoured destination station $A_{1}$ and $A_{2}$. For the finale choice it is necessary to select additional criteria [10].

For the mentioned numerical example it has been shown that new data are included in the mathematical model and that by using the game theory methods for the selection of the best route the solution is obtained if:

1) the experiment (survey) yields result $x_{1}$, strategy $a_{1}$ should be taken,

2) $x_{2}$ dominates, strategy $a_{2}$ should be selected,

3) $x_{3}$ dominates, strategy $a_{3}$ should be taken,

4) $x_{4}$ dominates then it is necessary to use the random choice mechanism among strategies $a_{1}$ (bus line to $A_{1}$ ) and strategy $a_{3}$ (bus line to $A_{3}$ ) with equal probability of $1 / 2$.

The result of the survey predetermines the choice of optimal solution on the route of the new bus line, since the data about the connection of the residents of the new settlement to certain stops in the city are input into the mathematical model. Only result $x_{4}$ shows that the residents of the new settlement do not prefer any of the destinations $A_{1}, A_{2}, A_{3}$ then from $A_{1}$ to $A_{3}$ the selection should be made in a random manner. Owing to additional statistical information obtained by surveying the residents of the new settlement the urban transport company can use the statistical games to select the optimal route for the new bus line to connect the settlement with the city centre. 


\section{Conclusion}

The matrix game theory, as a scientific discipline occurs in the decision-making processes primarily through the development of mathematical models and their usage in order to solve the real problems. Decisionmaking is an important part of the manager's work in various areas of economy. The traffic professionals make every day decisions and as one universal method for decision-making they can use quantitative decisionmaking methods, first of all matrix games. The traffic professionals apply in fact the developed matrix game methods to their problems using various software. The activity of the traffic professionals is to estimate the value of the matrix of payment using different methods. The main result of study in this paper is the application of the game theory to traffic planning in the cities, and it has shown how initial data can be connected to the newly gathered data.

In order to obtain high-quality decisions in traffic planning the quantitative methods of decision-making are increasingly used, where the game theory occupies a special place.

And finally, what should be specially emphasised is the latest trend in the area of decision-making which represents an attempt at the integration of expert systems and decision-making support systems in the new category, the so-called intelligent decision-making support systems.

\section{References}

[1] Bazerman, H. M. Judgement in Managerial Decision Making (second edition), Wiley and Sons, New York, 1990.

[2] Čileg, M.; Vugdelija, D.; Kiš, T. Operaciona istraživanja, Ekonomski fakultet, Subotica, 1996.

[3] Easley, D.; Kleinberg, J. Networks, Crowds, and Markets: Reasoning about a Highly Connected World, Cambridge University Press, 2010. DOI: 10.1017/CBO9780511761942

[4] Hammond, J.; Keeney, R.; Raiffa, H. Smart Choices, Harvard Business School Press, Boston, 1999.

[5] Jamnik, R. Teorija igre, Mladinska knjiga, Ljubljana, 1966.

[6] Koryagin, M. E. Game theory approach to optimizing of public transport traffic under conditions of travel mode choice by passengers. // Transport Problems. 9, 3(2014), pp. 117-124.

[7] Krčevinac, S. i dr. Operaciona istraživanja 2, Fakultet organizacionih nauka, Beograd, 2006.

[8] Martić, Lj. Primjena matematičkih metoda u ekonomskoj analizi - Zbirka zadataka, Informator, Zagreb, 1971.

[9] Martin, J.; Osborne, J. Introduction to Game Theory, Oxford University Press, 2003.

[10] Samuelson, L. Evolution and game theory. JEP. 16., 2002.

[11] Zhang, H.; Su, Y.; Peng, L.; Yao, D. A review of game theory applications in transportation analysis. // International Conference on Computer and Information Application (ICCIA), Tianjin, 2010. DOI: 10.1109/iccia.2010.6141559

\section{Authors' addresses}

Assoc. Prof. Jasmina Pašagić Škrinjar, Ph.D.

Faculty of Transport and Traffic Sciences

University of Zagreb

Vukelićeva 4, Zagreb, Croatia

E-mail: jpasagic@fpz.hr
Assist. Prof. Borna Abramović, Ph.D.

Faculty of Transport and Traffic Sciences

University of Zagreb

Vukelićeva 4, Zagreb, Croatia

E-mail: borna.abramovic@fpz.hr

Assist. Prof. Nikolina Brnjac, Ph.D.

Faculty of Transport and Traffic Sciences University of Zagreb

Vukelićeva 4, Zagreb, Croatia

E-mail: nikolina.brnjac@fpz.hr 